\title{
Department vs discount retail store patronage: effects of self-image congruence
}

\section{Authors: Eunyoung (Christine) Sung \& Patricia Huddleston}

This is a postprint of an article that originally appeared in Journal of Consumer Marketing May 2018. The final version can be found at https://dx.doi.org/10.1108/JCM-01-2016-1686.

Sung, Eunyoung (Christine), and Patricia Huddleston. "Department vs discount retail store patronage: effects of self-image congruence." Journal of Consumer Marketing 35, no. 1 (May 2017): 64-78. DOI:10.1108/JCM-01-2016-1686.

Made available through Montana State University's $\underline{\text { ScholarWorks }}$ scholarworks. montana.edu 


\title{
Department vs discount retail store patronage: effects of self-image congruence
}

\author{
Eunyoung (Christine) Sung \\ Jake Jabs College of Business and Entrepreneurship, Montana State University, Bozeman, Montana, USA, and \\ Patricia Huddleston \\ Department of Advertising and Public Relations, Michigan State University, East Lansing, Michigan, USA
}

\begin{abstract}
Purpose - This paper explores the antecedents and consequences of consumers' need for self-image congruence on their retail patronage of department (high-end) and discount (low-end) stores to purchase name-brand products in two product categories, apparel and home décor. It also compared online to offline shopping and considered two mediator variables, frugality and materialism.

Design/methodology/approach - The paper analyzed the hypothesized relationships using structural equation modeling (SEM) and MANOVA. Study 1 suggested the model using secondary data, and Study 2 measured and confirmed the relationships using scenario-based online survey data. An MANOVA test was used to compare the shopping behavior of consumers with high and low need for self-image congruence.

Findings - A strong causal link was found between concern with appearance and need for self-image congruence, and a positive relationship between need for self-image congruence and high- and low-end retail store patronage offline and online. While the group with high (vs low) need for self-image congruence was more likely to patronize department stores, unexpectedly, both the high and low self-image congruence groups were equally likely to shop at discount stores.

Practical implications - The findings suggest that marketing messages focusing on concern for appearance may succeed by tapping into consumers' need for self-image congruence with brand product/retail store images. Results also showed that consumers with high self-image congruence often patronize discount retail stores, suggesting marketing opportunities for low-end retailers.

Originality/value - Because consumers with high need for self-image congruence patronize both department and discount stores, it is suggested that self-image congruity may be multi-dimensional. The current study is also the first to examine structural relationships to test patronage behavior between department and discount stores offline and online.
\end{abstract}

\section{Introduction}

What motivates a consumer to select a high-end over a low-end retail outlet? What dictates their choices of how much money and time to spend shopping and which brands and products to buy? Previous studies have suggested that store patronage decisions are influenced by psychological factors such as selfconcept and self-image (Graeff, 1996, 1997; Heath and Scott, 1998; Jamal and Goode 2001; Sirgy et al., 1997, 2000). Selfconcept is defined as the representation of the thoughts and feelings by which individuals identify themselves. Theorists contend that consumers seek to purchase products that match their self-concept; these purchases, in turn, allow consumers to project ideal, or preferred, self-images into their social group interactions (Dolich, 1969; Sirgy, 1982). As a component of self-concept, self-image refers to how individuals perceive themselves (Sirgy, 1982). Graeff (1997) and Rosenberg (1979) contended that self-image is strongly related to a consumer's perception of his or her public appearance and other personal qualities (e.g. abilities, personalities). Researchers have found that consumers choose particular retail stores that also are consistent with, and thus maintain, their preferred self-image (Chebat et al., 2006; O'Cass and Grace, 2008).

Self-concept and self-image have been linked to consumer behavior through the concept of self-image congruence, defined as the consistency between the individual consumer and a brand/product image (Sirgy, 1982, 1986) or a retail store image (Chebat et al., 2006; O'Cass and Grace, 2008). Kressmann et al. (2006) defined this construct as "the match between consumers' self-concept (actual self, ideal self) and the user image (or 'personality') of a given product, brand, store, etc." (955). Sirgy $(1982,1986)$ found that the congruity between the self and the product image influences the consumer's purchase intentions and behavior. Particularly germane here, selfimage congruence can refer to a match between the consumer's 
image and that of the retailer (Kressmann et al., 2006). When making a purchasing decision, the consumer must first form a representational image of all the potential retail stores he or she can visit that fit within the confines of his or her self-image. For example, it could be that those who choose high-end retail stores (e.g. department stores) might find pleasure in the ambiance of the retail environment and purchasing experiences, as well as the upscale merchandise. Similarly, it is possible that those who patronize low-end retail stores (e.g. discount stores) might value utilitarian aspects of the experience, such as discount prices. For retail marketers, understanding the underlying psychological mechanisms of consumers' store patronage behavior allows them to tailor retail-marketing strategies to their store patrons. However, researchers in self-image congruence fields have not yet adequately addressed how this construct (specifically, consumers' level of need for self-image congruence with retailers they patronize) affects consumers' retail patronage behavior for high and low-end stores, either offline or online. This is the gap filled by the present study.

The purpose of our study is to investigate the relationship between consumers' need for self-image congruence (high- vs low-need) and their patronage of department stores vs discount stores (high-end vs low-end retail stores), both offline and online, with mediator effects of two consumer values (materialism and frugality). We posit that psychological characteristics (concern with appearance and need for selfimage congruence) that inform self-concept serve as a primary mechanism for retail patronage choice; thus, high- and low-end retail store patronages and buying name-brand products are the consequences of this mechanism. By identifying the relationships among these characteristics, this study provides scholars and retailers with insight into influences on consumer retail patronage choice and subsequent purchase of namebrand products. Understanding how consumers' need for selfimage congruence affects their decisions as to which stores to patronize will be helpful to retailers in designing marketing messages and merchandising strategies (Dolich, 1969; Sirgy, 1982).

\section{Study 1: toward a model for self-image congruence in retail store patronage}

For Study 1, we compared consumers with high and low need for self-image congruence in their patronage of two types of retail stores (department vs discount clothing stores) using two product categories (apparel and home décor).

\section{Self-image congruence and its relationship to other factors}

\section{Concern about appearance}

Self-concept theory defines self-image as individuals' perceptions of their personal qualities, including appearance (Graeff, 1997). In our study, we anticipated that consumers with a strong sense of self would be concerned with their appearance. Appearance is important in social interactions because it is the basis on which we recognize and judge ourselves and others (Jung and Lee, 2006). In the present study, we define concern about appearance as a person's interest in external beauty, including attractive dress and youthful appearance. According to self-schema theory, people are more likely to publicly change their behavior to fit with a group (Jung and Lee, 2006) if they have high self-schemas - organized cognitive self-representations (Markus, 1977). That is, people who are concerned about how they appear to the group, and alter their behavior accordingly, are those who have highly organized cognitive self-representations. These organized selfrepresentations are part of the individual's self-image. Therefore, an individual's concern for appearance can be posited to relate to his or her self-image. Graeff (1997) found that consumers who are concerned about their public representation are more likely to be those who need self-image congruence with a preferred image. Specifically, he investigated people's self-image congruence with various brands of beer, finding that when respondents were in public, they chose better, more expensive beer brands to reflect a preferred image. In this study, we hypothesize that this link between public representation, which we term concern about appearance, and need for self-image congruence can also be seen with other products, namely clothing and home décor. Therefore, the following hypothesis was proposed:

H1. There is a positive relationship between concern about appearance and need for self-image congruence.

Name-Brand consumption.

Consumers with high need for self-image congruence tend to use the brand image of highly evaluated name-brand products as a way to reflect their desired or ideal selves (Dolich, 1969). In our study, high (vs low) need for self-image congruence refers to the consumer's level of need for congruence between his or her self-image and the image of the retail stores he or she chooses to patronize. We understand retail store patronage as one strategy consumers may use to project their preferred selfimage. Kressmann et al. (2006) found that high (vs low) need for self-image congruence was positively related to perception of brand image, and that high need for self-image congruence positively affected brand consumption. Jamal and Goode (2001) found a positive relationship between need for selfimage congruence and brand preference for jewelry products. Graeff (1996) observed that consumers evaluated branded products more favorably when there was a high degree of congruence between brand image and self-image. Further, the degree to which consumers were self-monitors moderated the relationship between image congruence and brand evaluation for publicly (vs privately) consumed brands (Graeff, 1996). This finding suggests that, for brand consumption that is visible to others, consumers' self-congruity with the brand is particularly important. Thus, we conclude that consumers who have high need for self-image congruence between themselves and branded products are more likely to prefer name-brand products. In our study, we anticipated that consumers' need for self-image congruence (with clothing and home décor) would be shown to positively relate to preference for name-brand products. Therefore, the following hypothesis was tested:

H2. There is a positive relationship between consumers' need for self-image congruence and their preference for name-brand products. 
Retail store patronage and name-brand consumption

Consumers' (ideal or actual) self-image affects the entire shopping experience, from store patronage to actual product purchase. Perceived congruity between self-image and a retail store's image might help consumers to achieve an ideal selfimage (Chebat et al., 2006; O'Cass and Grace, 2008). Some consumers may use upscale stores to project an actual or desired high self-image. O'Cass and Grace (2008) concluded that a high need for self-image congruence with store image increased consumer patronage. Chebat et al. (2006) developed a model demonstrating that the social class image of a shopping mall is positively related to the types of stores consumers visit, and that consumers' need for self-congruity mediated this relationship. Therefore, we propose that a greater need for selfimage congruence leads to upscale mall retail store patronage while it negatively affects downscale retail store patronage. We hypothesized as follows:

H3. A greater need for self-image congruence is positively related to department (high-end) retail store patronage.

H4. A greater need for self-image congruence is negatively related to discount (low-end) retail store patronage.

In addition, consumers are more likely to be exposed to luxury name-brand products (e.g. Louis Vuitton) in department stores (e.g. Nordstrom) than in discount stores (e.g. Wal-Mart). Thus, we also suggest that consumers who patronize high-end retail stores are more likely to prefer name-brand products, and that consumer patronage of low-end retail stores is negatively related to preference for name-brand products. Therefore, the following hypotheses were tested:

H5. Department (high-end) store patronage is positively related to the consumer's preference for name-brand products.

H6. Discount (low-end) store patronage is negatively related to the consumer's preference for name-brand products.

As mentioned in the previous section, Graeff's (1997) selfimage congruence study found that respondents chose better (i.e. more expensive, reputable) beer brands in public places than they chose to purchase for consumption in their homes, indicating that they preferred to broadcast an image in public that differed from their private selves. Purchasing highly regarded brands in public enabled consumers with high need for self-image congruence to project an ideal self. Following Graeff (1997), we propose that consumers with a high need for self-image congruence are more likely to seek out better/ preferred products and brands as a means to project a certain image in public. Our study will support Graeff's (1997) findings if the group with high need for self-image congruence patronizes department (high-end) stores more frequently than they do discount stores. In this case, the group with a high need for self-image congruence will be less inclined to low-end (discount) store patronage. We hypothesize as follows:

H7. Consumers with a higher need for self-image congruence have greater department (high-end) store patronage than do consumers with low need for self-image congruence.
H8. Consumers with higher need for self-image congruence have lower discount (low-end) store patronage than do consumers with low need for self-image congruence.

\section{Methods}

Data collection and sample

A purchased secondary data set from the firm DDB Worldwide, which collects lifestyle data annually, was used to test the hypotheses. Participants were adult consumers who took the Market Facts in the USA Survey, a part of the DDB Lifestyle Study. Participants shopped regularly in department and discount stores. Among approximately 5,000 male and female panelists, a total of 3,345 valid responses were used for the SEM model. To adjust subcategories of race, gender and marital status to reflect the US population, US census information for Adult Heads-of-Household was used. This study's sample included 1,588 males (47.5 per cent) and 1,757 females (52.5 per cent). Most respondents were married (70 per cent). Appendix 1 shows specific characteristics of respondents that were included in the main structural model.

\section{Measurements and procedure}

Questions from the DDB Market Facts Survey were used to measure concern with appearance, need for self-image congruence and consumption of name-brand products. All questions were measured on a six-point Likert scale, from definitely disagree (1) to definitely agree (6). For concern with appearance, six items were used (e.g. "I enjoy getting dressed up" [Appendix 2]). For the need for self-image congruence, three items were included (e.g. "The brands I buy are a reflection of who I am"). For consumption of name-brand products, three items were used (e.g. "I try to stick to wellknown brand names").

In addition, questions were used to measure high- and lowend retail store patronage. To measure department store patronage, two items were used, using a seven-point Likert scale $(1=$ none to $7=52+$ times $)$. These questions were: "Purchased clothes at a department store during the past 12 months (e.g. Dillard's, Saks, Nordstrom)," and "Purchased items for your home at a department store during the past 12 months (e.g. Dillard's, Saks, Nordstrom)." To measure discount retail store patronage, two questions were used, measured on a seven-point Likert scale $(1=$ none in the past year to $7=52+$ times). These questions were: "Purchased clothes at a discount retailer during the past 12 months (e.g. Wal-Mart, Kmart, Target)" and "Purchased items for your home at a discount retailer during the past 12 months (e.g. Wal-Mart, Kmart, Target)".

\section{Results from the structural model}

To check for construct validity, confirmatory factor analysis (CFA) was conducted on constructs with multi-item indicators: concern about appearance, need for self-image congruence, name-brand consumption, high-end (e.g. department store) retail store patronage and low-end retail store patronage. AMOS 18 software with maximum likelihood estimation was used for the analysis. Before CFA analysis, six questions from the dataset related to "appearance" were 
chosen. Only four of six items were retained after CFA. Appendix 2 shows standardized factor loadings, composite reliability and average variance extracted values. The result of CFA indicated good fit statistics of model $1\left(\chi^{2}=838.26, p<\right.$ $0.001 \mathrm{df}=67, \mathrm{GFI}=0.97, \mathrm{AGFI}=0.95, \mathrm{NNFI}=0.88, \mathrm{NFI}=$ $0.91, \mathrm{CFI}=0.91, \mathrm{RMSEA}=0.06)$. These indices of CFI or IFI were greater than 0.90 as the cutoff (Bollen, 1989), and RMSEA was between 0.05 and 0.10 (MacCallum et al., 1996). The $\chi^{2} / \mathrm{df}$ test (Hooper, Coughlan, and Mullen, 2008) was not desirable because of the use of secondary data, but we improved this fit in Study 2 using primary data.

Construct validity was measured by convergent and discriminant validity tests. The convergent validity tests showed that all factor loadings were significant at the $p<0.001$ level. Convergent validity was established, as the factor loadings were indicators of the expected latent variables, demonstrating that the majority of factor-loading coefficients were above or around 0.5 at a significance level of $p<0.001$ (Anderson and Gerbing, 1988). This means that measured scales are consistent with the theoretical constructs and is evidence of convergent validity. For discriminant validity, each item loading within the same latent construct should be within its respective latent construct, as distinguished from any other latent construct (Kline, 2005). The items presented in Appendix 2 were classified into the theoretically targeted construct and achieved discriminant validity. If the average variance extracted (AVE) for constructs is greater than the shared variance between two constructs, the constructs are different (Fornell and Larcker, 1981). Appendix 2 shows the measurement properties of the current study.

To test the hypothesized causal relationships between constructs, AMOS 18 was used for structural equation modeling analysis using maximum-likelihood estimates (Jöreskog and Sörbom, 1993). The study model fits show as follows: $\chi^{2}=974.26, \mathrm{df}=71, p<0.001, \mathrm{GFI}=0.96$, AGFI $=$ $0.94, \mathrm{NNFI}=0.87, \mathrm{NFI}=0.89, \mathrm{CFI}=0.90, \mathrm{RMSEA}=0.06$ (Figure 1).

We tested our hypotheses based on the structural equation modeling. Figure 1 and Appendix 4 summarize the results of

Figure 1 Antecedents and consequences of consumers' need for selfimage congruence: standardized structural path estimates (Study 1)

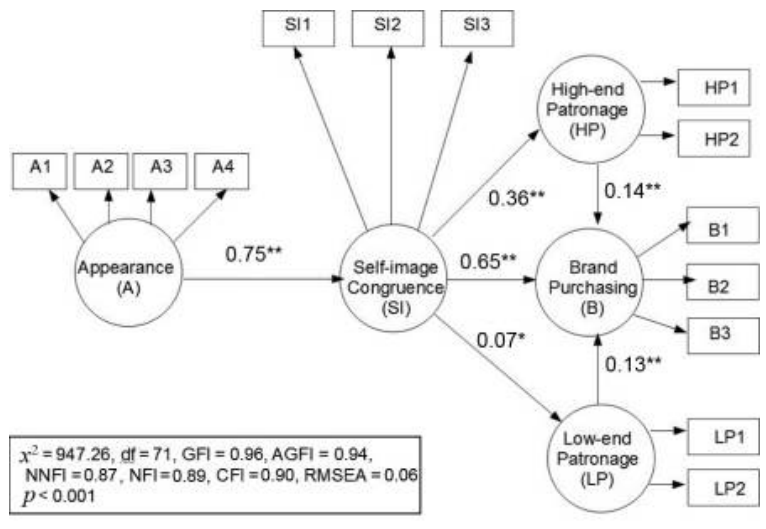

Notes: $p<0.001^{* *}, p<0.05^{*}$; "High-end" means department stores; "low-end" means discount stores) hypothesis tests of Model 1. H1 posited that there is a positive relationship between concern about appearance and need for self-image congruence with products. The results showed a positive relationship between concern with appearance (A) and need for self-image congruence (SI) and supports $H 1\left(\gamma_{1}=\right.$ $0.75, p<0.001) . H 2$ posited that there is a positive relationship between need for self-image congruence (SI) and preference for name-brand products (B) $\left(\beta_{1}=0.65, p<0.001\right)$. Thus, $H 2$ was supported. $H 3$ posited that need for self-image congruence is positively related to high-end (e.g. department stores) retail store patronage $(\mathrm{HP})\left(\beta_{2}=0.36, p<0.001\right)$. H3 was supported. $H 4$ posited that need for self-image congruence (SI) is negatively related to low-end (LP) retail store patronage. However, this hypothesis was not statistically supported $\left(\beta_{3}=\right.$ 0.07, $p<0.05)$. Instead, results showed a statistically significant, but weak, positive relationship. $H 5$ posited that high end retail store patronage is positively related to the consumer's preference name-brand products $(\mathrm{B})\left(\beta_{4}=0.14, p<0.001\right)$. H5 was supported. H6 posited that low end retail store patronage is negatively related to the consumer's preference for name-brand products $(\mathrm{B})\left(\beta_{5}=-0.13, p<0.001\right)$. Therefore, H6 was supported.

\section{High versus low need for self-image congruence on high- versus low-end store patronage}

The subsequent analysis addresses the retail patronage behavior of groups with high versus low need for self-image congruence. We separated participants as follows: Three selfimage congruence items, measured on a six-point Likert scale ( 1 = definitely disagree), were summed and averaged. Then, the participants who had an average score between 1 and 2 were included in the group with low need for self-image congruence, while participants who scored between 5 and 6 were included in the high-need group to test $H 7$ and $H 8$. We established the middle self-image congruence group as ranges between scores 3 and 4 , as a reference group between the low and high self-image congruence groups. A total of 1,038 participants were used for the high versus low self-image congruence group comparisons $($ male $=491,47.3$ per cent; female $=547)$, while the group of 2,303 participants with moderate need for self-image congruence was the reference group. The group with high need for self-image congruence contained 636 participants (male $=$ 269, 42.3 per cent; female $=367$ ), and the low-need group contained 402 participants (male $=222,55.2$ per cent; female $=180$ ).

Figure 2 shows the results of the analysis comparing the groups with high versus low need for self-image congruence. To test $H 7$ and $H 8$, we compared department versus discount retail store patronage behavior for high and low self-image congruence (SIC) consumers by using MANOVA. $H 7$ and $H 8$ investigated the main effect of SIC (high and low need for SIC with a mid-group as reference) on the dependent measures. We used an MANOVA, followed by a series of post hoc tests with high, low and middle SIC groups. We found significant differences for high-end store patronage, Wilk's $\lambda=0.97, F(8$, $6670)=14.25, p<0.001$, partial $\eta^{2}=0.017$.

Supporting $H 7$, we found that consumers with high need for self-image congruence had higher department store patronage than those in the low-need group. The results are as follows: Mean scores of department store patronage were: $M_{\text {Apparel Dept. }}$ 
Figure 2 Patronage of department (high-end) versus discount (low-end) stores for groups with high versus low need for self-image congruence

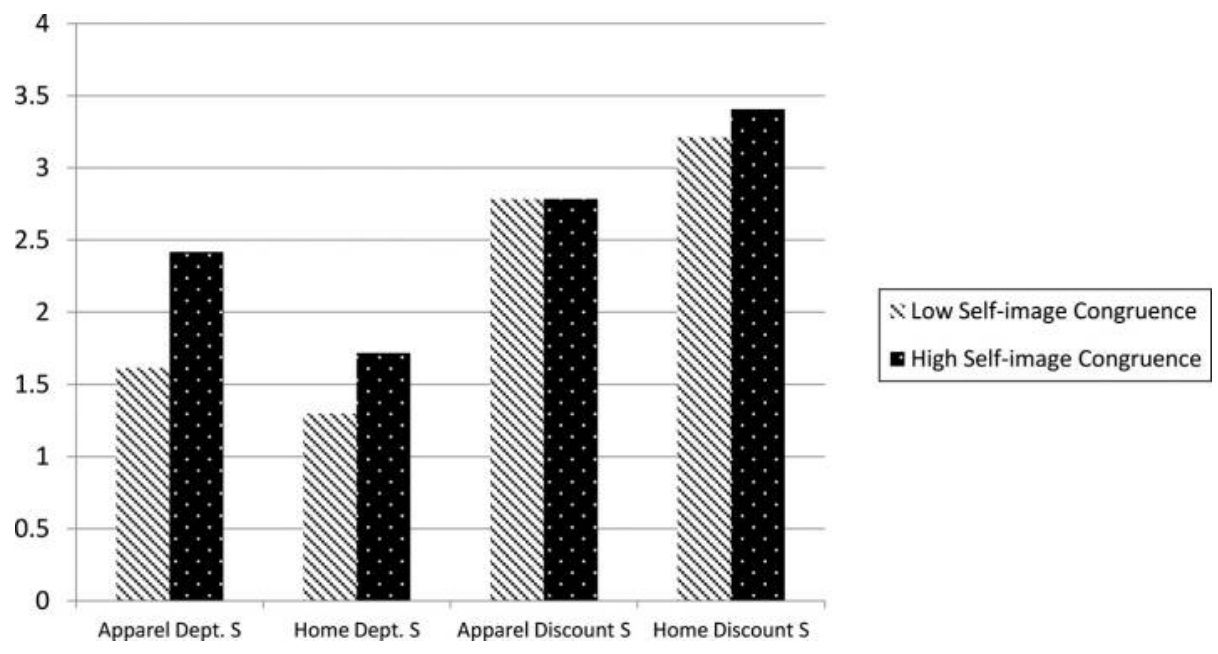

HighSI $=2.416, \mathrm{SD}=1.420$ (high self-image group) versus $M_{\text {Apparel Dept. } \text { MidSI }}=2.068, \mathrm{SD}=0.027$ (middle self-image group) versus $M_{\text {Apparel Dept. LowSI }}=1.613, \mathrm{SD}=0.97$ (low self-image group); $F(2,3338)=48.794, p<0.001$, partial $\eta^{2}=$ 0.028 . Mean scores of discount store patronage were: $M_{\mathrm{Home}}$ Dept. HighsI $=1.717, \mathrm{SD}=1.107$ (high self-image group) versus $M_{\text {Home Dept. } \text { MidSI }}=1.484, \mathrm{SD}=0.019$. (low self-image group) versus $M_{\text {Home Dept. LowSI }}=1.296, \mathrm{SD}=0.67$ (low self-image group); $F(2,3338)=27.754, p<0.001)$, partial $\eta^{2}=0.016$. Post hoc tests showed statistical differences between all three groups (Bonferroni; $p<0.001$ ).

$H 8$ posited that the group with high need for self-image congruence has lower discount store patronage for apparel and home décor products than the low-need group. However, highand low-need groups showed no significant differences for discount store patronage. Thus, $H 8$ is not supported.

The findings indicate that for clothing and home décor shopping, consumers with low need for self-image congruence tend to go to department stores less frequently than high-need consumers, while consumers in the high-need group patronize not only department stores, but also discount stores, as often as those in the low-need group. Appendix 4 shows the results of hypothesis testing.

\section{Discussion}

The results of the study revealed a strong causal connection between concern about appearance and need for self-image congruence; specifically, we found that interest in appearing, for example, young and professional, influences need for selfimage congruity. Second, we also found that preference for name-brand products was positively linked to department store patronage and negatively linked to discount store patronage, perhaps because consumers have more access to name-brand or expensive products in department stores. As expected, need for self-image congruence was strongly linked to brand preference (Dolich, 1969; Kressmann et al., 2006). Consumers with high need for self-image congruence prefer well-known branded products as a means to project their preferred images via brands, even if they obtain branded products cheaply in discount stores. A third finding states that high need for selfimage congruence is related to department store patronage. Existing research says that consumers' need for self-image congruence is related to a preference for brands (Dolich, 1969; Graeff 1996; Jamal and Goode 2001; Kressmann et al., 2006), and store patronage (Ibrahim and Najjar, 2007; Sirgy et al., 2000). However, we also unexpectedly found a statistically significant, albeit weak, positive relationship between need for self-image congruence and discount store patronage.

We also conducted analysis comparing the influence of high (vs low) need for self-image congruence on department versus discount store patronage. We found that consumers with high need for self-image congruence patronized department stores more often than the low-need group. However, statistical results also showed that high- and low-need groups patronized discount stores in apparel and home décor categories with equal frequency. We propose five explanations for this result: public versus private consumption, price mavenism, frugality, the "cool" image of some discount products, and individualism.

First, it seems possible that the differing psychology of public versus private consumption behavior explains why consumers with high self-image congruence patronized both department stores and low-end retail stores. As Graeff (1997) showed, consumers chose different beer brands depending on the purpose of usage (public vs private), presumably because they sought to maintain a preferred image in public. Similarly, in our study, consumers with high need for self-image congruence patronize both high- and low-end stores when shopping for home décor and clothing products, as these are used for both public and private consumption. These results suggest that some consumers might desire to purchase name-brand home décor products or apparel to maintain their preferred images in public, but that they might not be willing to pay for brands for certain products in private, or for private use. This behavior might help explain the weak, but significant relationship between need for self-image congruence and discount store patronage in our main structural model. 
Another potential explanation for the finding that consumers with high need for self-image congruence patronized both department stores and low-end retail stores is that these consumers engage in price maven behavior. Price mavenism refers to consumers' concerns about others' opinions of the price they paid; it includes the desire to share low-price information to indicate that they are savvy shoppers (Feick and Price, 1987; Lichtenstein et al., 1993; Sternquist et al., 2004). Some consumers like to inform others about their success in finding bargains to boost their own self-image (Huddleston and Minahan, 2011). The price maven concept would suggest that consumers view shopping at discount stores as self-congruent because buying the desirable brand product at an attractive discount price could be a positive way to project shopping savvy.

A third explanation for why consumers with high need for self-image congruence would patronize low-end retail stores is frugality: the purchase of items based on valueconsciousness and price, rather than materialistic reasons (Lastovicka et al., 1999; Wells, 1993). Perhaps those with a need for high self-image congruence may patronize discount stores because their self-image says that they are frugal shoppers. Finding well-known brand products at low prices reflects their self-image as frugal, while still allowing them to project their preferred high self-image in their social groups because the retail "origin" is not obvious to others in one's social group. Frugality was not measured in Study 1 but was considered as a mediator in Study 2.

A fourth possible explanation as to why high need for selfimage congruence does not make consumers less likely to shop at a low-end retail store is that they may patronize a type of discount store, such as Target, that has established a "cool" and somewhat "high fashion" image. At this type of discount store, consumers might find limited quantities of designer merchandise, such as Target's recent offering of Lily Pulitzer merchandise.

Finally, individualism might drive the varied patronage of consumers with high need for self-image congruence. Individualism, an ideology with great currency in the USA, encourages individuals to seek self-interest and individual expression. As Hofstede (1984) explained, "the ties between individuals in individualist societies are loose" (p. 35). Research on Chinese consumers has shown that for this population, Confucian values such as thrift, persistence and self-discipline drive their store selection (Schwartz, 1992; He and Mukherjee, 2007). Thus, store choice can be driven by the values of consumers' society at large ( $\mathrm{He}$ and Mukherjee, 2007). Participants in our study, as American consumers, might patronize both department and discount stores as a means to express their individual identities.

In summary, the results of the current study are as follows:

- Consumers' perception of their appearance is the primary causal mechanism as an antecedent of their need for selfimage congruence; and

- Discount store patronage is related to need for self-image congruence.

Departing from previous self-image congruence studies, we found that self-image congruity may be multi-dimensional, as indicated by the fact that consumers with high need for selfimage congruence patronize both department and discount stores. The influence of the price maven effect, individualism and frugality may differ in different cultures and should be explored in future studies. This additional interpretation of self-image congruence constitutes our contribution to the existing literature.

Because Study 1 was based on secondary data and was focused on only one antecedent and causal mechanism for selfimage congruity, Study 2 developed targeted questions to explore a broader spectrum of factors, such as personal value characteristics like materialism and frugality. Thus, in Study 2, we conducted a scenario-based online study, extending Study 1 by adding mediators and the online channel for retail store patronage. By developing measurements that used additional factors to investigate the construct of interest, our second study confirmed Study 1 findings.

\section{Study 2: self-image congruence and retail store patronage}

\section{Background}

In Study 2, we conducted a scenario-based online study and retested $H 1$ and $H 3$. Based on the results of study 1 , we restated H4:

$H 4 \_R$. A greater need for self-image congruence is positively related to discount (low-end) store patronage.

We extended Study 1 by adding online retail purchase patronage, as well as two mediator variables, materialism and frugality. In testing this revised hypothesis from Study 1, we investigated whether high need for self-image congruence is also positively related to low-end (discount) store patronage. We added frugality as a mediator to assess whether it might explain why the need for self-image congruence was positively related to low-end store patronage. We added materialism as a mediator to see whether this, too, might influence self-image on high-end store patronage.

\section{Consumer values: frugality and materialism}

Among the consumer values identified by researchers are frugality and materialism. Frugality is defined as "a consumer lifestyle trait characterized by the degree to which consumers are both restrained in acquiring and resourceful in using economic goods and services to achieve longer-term goals" (Lastovicka et al., 1999, p. 88). Consumers who incline toward frugality as part of their self-image (Nguyen et al., 2015) could heighten this component in their consumer behavior by shopping at discount stores. A contrasting consumer value, materialism, is characterized by a preference for showing wealth status (Podoshen and Andrzejewski, 2012). Materialistic consumers are segmented as the largest target market for luxury brands (Wiedmann et al., 2009; Gil et al., 2012). Materialistic consumption behavior in an individual can be influenced by discrepancies between the individual's actual and ideal self-image, and can boost actual and ideal and selfimages (Mittal, 2015). Therefore, in consumers' choice of which retail stores they patronize, materialism mediates need for self-image congruence on high-end stores. Thus, we hypothesize as follows: 
H9. Materialism partially mediates need for self-image congruence on department (high-end) store patronage.

H10. Frugality partially mediates need for self-image congruence on discount (low-end) store patronage.

Felix and Garza (2012) identified a correlation between materialism and concern about body appearance among female students. In that study, when women consumers were concerned about their body appearance, they tended to purchase more material possessions. Therefore, materialism could also mediate the relationship between concern about appearance and high-end store patronage:

H11. Materialism partially mediates appearance on department (high-end) store patronage.

\section{Retail store channels: online versus offline high-and low-end retail store patronage}

In Study 1, we tested groups with high versus low need for selfimage congruence in terms of their retail store patronage of high versus low-end offline stores. For Study 2, we extended the scope to include online retail store patronage. As noted, Graeff (1997) found that consumers made different brand choices in public versus private contexts. Study 1 found a match between the high need for self-image congruence and the patronage of department stores; we also found that consumers in both groups, with high and low need for self-image congruence, were equally likely to patronize discount stores. Based on these findings, we would expect similar differences in offline versus online shoppers' behavior. Therefore, we hypothesize as follows:

H12. There is a difference between the self-image congruence groups (high- vs low-need) for department (high-end) retail patronage (a) offline and (b) online.

H13. There is no difference between the self-image congruence groups (high- vs low-need) on discount (low-end) retail patronage (a) offline and (b) online.

Self-image congruence encompasses both actual and ideal selfimage congruence (Sirgy et al., 1997). When people interact with others, they prefer to present their ideal self-image and pursue self-image congruity between preferred brands/ products and themselves. Therefore, we extrapolated the offline (public) and online (private) retail channel constructs to this study. Offline high-end retail store patronage is public and visible to close and distant others, while online high-end retail store patronage is private and not visible to others. We posit that consumers will more closely relate an ideal self-image to a higher-end, offline shopping context, versus an online context. Therefore, for a group of consumers with high need for selfimage congruence between themselves and the retail store image, these consumers would respond more strongly to an offline high-end retail store than to an online high-end retail store. Further, when this same group patronizes low-end stores, retail store channel (online vs offline) should not matter. Put simply, we expect that when consumers shop in public, they show off to match with their ideal self-image, making choices that are congruent with their preferred self, and when they shop in private (online), the same consumers buy cheaper brands. Therefore, the following hypothesis is proposed:

H14a. Consumers with need for high self-image congruence have stronger offline department (high-end) store patronage than online department (high-end) patronage.

H14b. Consumers with low need for self-image congruence have equal offline and online department (high-end) patronage.

\section{Method}

To provide insight into our research questions and test our proposed hypotheses, we conducted an online survey. Hypothesized relationships were tested, and we analyzed these relationships using ANOVA and structural equation modeling (SEM).

\section{Data collection and sample characteristics}

We sourced participants from a midwestern state university using the SONA system, an online student pool. Participants received course credit for completing the survey. The sample consisted of 195 participants, of which 167 responses were usable after data cleaning (using an attention check question). Of the 167 responders, 41.9 per cent were male, and 58.1 per cent were female. The majority was between 18 and 26 years old.

\section{Measurements and procedure}

After participants read an introductory paragraph asking them to imagine that they were considering the purchase of business apparel for a career fair, they responded to a series of questions that measured concern about appearance, need for self-image congruence, offline and online high- (low-) end retail store patronage, materialism and frugality. All questions were measured on a seven-point Likert scale from "strongly disagree" (1) to "strongly agree" (7). For appearance, 13 items were used, as modified from the previous study (Cash and Labarge, 1996). To rate self-image congruence, five items were used initially (Sirgy et al., 1997), and three items were maintained after the measurement (CFA) test. For store patronage, three modified questions were used to measure online high-end, offline high-end, online low-end and offline low-end retail store patronage constructs (Baker et al., 1992). Materialism was measured with seven items (Richins, 1987), and three items were maintained after the measurement (CFA) test. For frugality, eight questions were used (Brannick, 2003), and three items were maintained after the measurement (CFA) test. Appendix 3 shows the measures after the measurement tests.

\section{Results}

To test the hypothesized paths, we used SEM in conjunction with LISREL, version 9.20. We tested the convergent and discriminant validities of the constructs. After the measurement 
confirmatory factor analysis (CFA) tests, the suggested structural models (SEM) were tested.

\section{Structural equation modeling (SEM) for hypothesis tests}

To check for construct validity, measurements with multi-item indicators (concern with appearance, need for self-image congruence, high and low-end retail patronage, materialism and frugality) were analyzed by CFA. The software used for the CFA tests was LISREL 9.20 with maximum likelihood estimation. The retained items after CFA tests, based on LISREL's modification indices, are shown in Appendix 3 with standardized factor, composite reliability and average variance extracted values. The results of CFA indicated acceptable fit (Bollen, 1989; MacCallum et al., 1996; Hooper et al., 2008) statistics $\left(\chi_{(137)}^{2}=318.71, p<0.001, \mathrm{CFI}=0.907, \mathrm{IFI}=\right.$ $0.908 \mathrm{RMSEA}=0.08, \chi^{2} / \mathrm{df}=2.3$ ).

Convergent and discriminant validity tests were conducted to verify construct validity with all retained factor loadings at the significance level $(p<0.001)$. To establish construct validity, indicators were the expected latent variables, indicating that factor-loading coefficients were above or around 0.5 at a significance level of $p<0.001$ (Anderson and Gerbing, 1988). For discriminant validity, each item loading should fall into its respective latent construct (Kline, 2005). Appendix 3 shows the measurement properties as achieved constructs. The measurement validities were tested using discriminant validity, and the average variance extracted (AVE) was shown to be greater than the shared variance between two constructs (Fornell and Larcker, 1981). To test potential common method bias, we applied Harman's one-factor test (Podsakoff et al., 2003) to our data. During the procedure, a single latent factor was tested for all manifest variables. Then, we compared model differences between a single factor and our suggested multiple factors in the measurement. The results indicated that the model fit of the single-factor was significantly worse than the model fit of our suggested multiple factors, as a significant increase in $\chi^{2}$ shows $\left(\Delta \chi^{2}=1289.351, \Delta \mathrm{df}=15, p<0.0001\right)$. Therefore, common method bias did not significantly affect our results.

To test the hypothesized paths between constructs, LISREL version 9.20 was used for structural equation modeling analysis using maximum-likelihood estimates (Jöreskog and Sörbom, 1993). The study SEM model fits show as follows: $\chi^{2}{ }_{(155)}=$ 346.661, $p<0.001, \mathrm{CFI}=0.907, \mathrm{IFI}=0.908, \mathrm{RMSEA}=$ 0.086 . Figure 3 shows our final structural model with the SEM results, after we tested a competing model with mediators (a competing model using two-dot lines).

$H 1, H 3$ and $H 4 \_R$ all confirmed Study 1 results. $H 2, H 5$ and H6 (name-brand consumption) were not tested again in Study 2 because we considered the tests in Study 1 conclusive. H1 posited that concern with appearance is positively related to self-image congruence. This structural path was statistically significant $(\beta=0.304, p<0.01)$. Thus, H1is supported by Study 2 . H3 posited that self-image congruence is positively related to high-end store patronage. The path was statistically significant $(\beta=0.365, p<0.01)$, supporting $H 3$. $H 4 \_R$ posited that self-image congruence is positively related to low-end store patronage. This structural path was statistically significant $(\beta=$ $0.170, p<0.05)$, validating $H 4 \_R$.
Figure 3 Structural model (study 2)

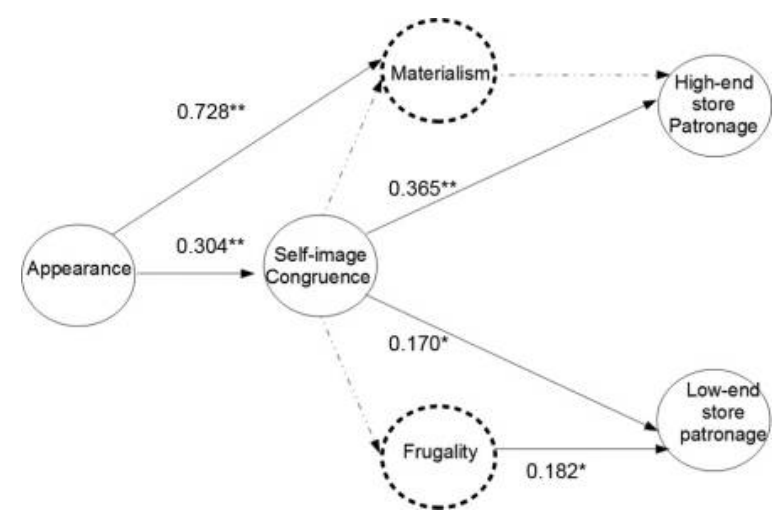

H9, H1O and H11 in Study 2 were not supported, but we found that frugality explains low-end store patronage. $H 9$ posited that materialism partially mediates need for self-image congruence on high-end store patronage. The path to test the mediator effect was not statistically significant. Thus, based on the results of the mediator (materialism) test, materialism does not mediate the relationship between self-image congruence and high-end store patronage. H10 posited that frugality partially mediates need for self-image congruence on low-end store patronage. The test of the mediator effect shows it is not statistically significant, but the direct path coefficient between frugality and low-end store patronage was significant $(\beta=$ $0.182, p<0.05)$. Thus, frugality does not mediate the relationship between need for self-image congruence and lowend store patronage. However, frugality itself appears to explain low-end store patronage behavior, a point that will be taken up in the discussion below. In addition, $\mathrm{H} 9$ posited that materialism partially mediates concern with appearance on high-end store patronage. Only one path between concern with appearance and materialism $(\beta=0.728, p<0.01)$ was significant, and there was no significant path between materialism and high-end store patronage. Therefore, $H 6$ is not supported.

\section{MANOVA for hypothesis tests}

To test H12, H13 and H14, an MANOVA (see Table I) with Tukey post-hoc tests was conducted (High SIC for offline and online patronage, Low SIC for offline and online patronage). The result is Wilks' $\lambda=0.93, F(4,162)=2.88, p<0.001$, partial $\eta^{2}=0.066$ between subjects' effects. $H 12$ posited a significant difference between the two groups (those with high and low need for self-image congruence [SIC]) on high-end retail patronage (a) offline and (b) online. Specifically, H12(a) tested the relationship between high versus low need for SIC and high end offline store patronage. The hypothesis was statistically supported as follows: (High SIC Mean offline $=5.34$, $\mathrm{SD}_{\text {offline }}=1.19$ vs Low SIC Mean offline $=4.72, \mathrm{SD}_{\text {offline }}=1.27$; $t=-3.21 F(1,165)_{\text {offline }}=10.29, p<0.01$, partial $\left.\eta^{2}=0.059\right)$. $H 12$ (b) analyzed the difference between the high versus low need for SIC on high end online store patronage. Results supported H12(b): (High SIC Mean online $=5.02, \mathrm{SD}_{\text {online }}=$ 1.57; Low SIC Mean online $_{1}=4.44, \mathrm{SD}_{\text {online }}=1.67 ; t=-2.28$. $F(1,165)_{\text {online }}=5.18, p<0.05$, partial $\left.\eta^{2}=0.030\right) . H 13$ posited no difference between the groups with high and low 
Table I High versus low need for self-image congruence and retail patronage offline and online

\begin{tabular}{|c|c|c|}
\hline Patronage & High SIC: Mean (SD) & Low SIC: Mean (SD) \\
\hline \multicolumn{3}{|l|}{ 1) Offline High } \\
\hline End Patronage & $5.34(1.19)^{*}$ to Low SIC & $4.72(1.27)$ \\
\hline \multicolumn{3}{|l|}{ 2) Offline Low End } \\
\hline Patronage & $5.15(1.65)$ & $4.93(1.51)$ \\
\hline \multicolumn{3}{|l|}{ 3) Online High End } \\
\hline Patronage & $5.02(1.57)^{*}$ to Low SIC & $4.44(1.67)$ \\
\hline \multicolumn{3}{|l|}{ 4) Online Low End } \\
\hline Patronage & $4.48(1.81)$ & $4.07(1.72)$ \\
\hline \multicolumn{3}{|c|}{$\begin{array}{l}\text { Notes: High SIC }=\text { High self-image congruence }(>4.5) \text {; Low SIC }=\text { Low } \\
\text { self-image congruence }(<4.4) ; 1 \text { (strongly disagree)-7 (strongly agree) } \\
\text { Likert scale; }{ }^{*} p<0.05\end{array}$} \\
\hline
\end{tabular}

need for self-image congruence in terms of low-end retail patronage (a) offline and (b) online. H13 was supported, that is, there was no difference between the high- and low-need groups in terms of low-end retail patronage for either an offline or online channel.

H14 compared high-end store patronage across the online and offline channels. It posited that (a) consumers with high need for self-image congruence have stronger offline high-end store patronage than online high-end patronage, whereas (b) consumers with low need for self-image congruence have equal offline and online high-end patronage. There was no significant difference in high-end store patronage between the two channels. Thus, $\mathrm{H} 14 a$ was not statistically supported, but $H 14 b$ was supported. Appendix 4 summarizes the results of hypothesis testing.

\section{Discussion}

Our study contributes to an understanding of consumer behavior at different levels of self-image congruence (high vs low), for two types of retail store patronage choice (high-enddepartment vs low-end-discount), and two channels of retail stores (offline vs online) mediated by consumer values (materialism and frugality). In Study 2, we found a relationship between concern about appearance and need for self-image congruence. This finding extends Study 1 and the literature on appearance, self-schema and self-image congruence (Markus, 1977; Jung and Lee, 2006; Graeff, 1997) to include the influence of these constructs on store patronage. Appearance is known to be important in social interaction. A higher concern for appearance leads to higher need for self-image congruence between the consumer and name-brand products, as the consumer attempts to project an ideal self-image in public.

Study 2 confirmed that consumers' need for self-image congruence is positively related to low-end store patronage. We did not find literature to explain the relationship between the need for self-image congruence and low-end store patronage; however, we provided a rationale for this result by drawing on the literature that shows savvy shoppers enjoy sharing low-price information (Feick and Price, 1987). In a previous study, consumers liked to share their shopping success stories (i.e. finding the best price) with their friends and family to boost their own self-image (Huddleston and Minahan, 2011). We predicted that frugality provides an explanation for this behavior, that is, frugality mediates the need for self-image congruence on low-end store patronage. Study 2 did not find evidence of this mediation, but we did find that frugality directly influenced low-end store patronage. We can conclude that more frugal consumers patronize low-end retail stores regardless of self-image. This finding may suggest that frugal characteristics are separate from one's self-image, but that frugality still influences the decision to shop at a discount store. Hunting for treasure such as discounted name-brand items in discount stores might give shoppers pleasure in ways that are unrelated to frugality itself.

Previous studies discovered that consumers patronize retail stores to help to achieve an ideal image through congruence between oneself and a retail store's image (Chebat et al., 2006; O'Cass and Grace, 2008). Our study confirms this, showing that the need for self-image congruence is positively related to high-end store patronage and that when consumers have high self-image congruence with a high-end retail store image, they patronize that store. The purchase enables the consumer to present a preferred image.

Although we found that concern for appearance was directly related to materialism, we did not find evidence for the hypothesis that materialism mediates the relationship between (a) need for self-image congruence and high-end store patronage, or (b) concern with appearance and high-end store patronage. That is, materialism has no impact on high-end store patronage. This result might be because of the young age of this study's participants, as most may not yet have held a fulltime job. The financial strain of being university students might forestall young consumers' development of materialistic values. Meanwhile, it is worth noting that the role of materialism in purchasing decisions might differ for men and women, as women tend to prefer more fashionable clothing items.

Study 2 provided further evidence that groups with high versus low need for SIC have different patronage behaviors for offline stores, and offered parallel results for online shopping. Specifically, the high-need group patronized high-end stores more frequently than the low-need group. However, there was no difference between high- versus low-need groups for lowend store patronage intention, either offline or online.

We had assumed that the group with high need for SIC would have higher offline high-end store patronage than online high-end store patronage because this offline type of consumption is more public. Our results indicated that, for the high-need group, there was no difference between offline and online high-end store patronage intention. However, consumers with high need for SIC were more likely to patronize a high-end store regardless of whether consumption was public (offline) or private (online). Thus, it appears that even though online shopping behavior is not visible to others, maintaining congruence between self and retail brand matters for the highneed group, to the extent that both channels are shopped equally. This consistent behavior suggests that regardless of whether shopping behavior is public or private, consumers with high need for SIC work to maintain an ideal self-image. We also conclude that for high-end stores, consumers are consistent in their perception that shopping at either an online or offline setting should match their self-image. Unlike Graeff's (1997) 
study on beer consumption where consumers purchased different brands for public versus private consumption, our study indicated that when consumers with high need for SIC shop for business apparel, they are more likely to choose to shop in a high-end retail store, whether shopping in private (online) or public (offline). Taking the business apparel as an example, no one would know the source of the apparel unless the consumer chose to mention it. So, does the consumer feel more confident in knowing that an outfit was purchased from a high-end store, even if there is no visible evidence of the merchandise source? Further study is needed to tease out the underlying reasons for some consumers' tendency to purchase from a high-end store even when the store patronage choice remains private.

For both studies, we found consistent results for low-end store patronage. That is, there was no difference between the groups with high and low need for SIC for low-end shopping patronage. Adding the online context for Study 2 produced similar results. While these studies did not explore motivations for shopping at low-end stores, it is likely that consumers are aware of the availability of high-end brands at some discount stores. The availability of these preferred brands at lower prices may be an underlying reason for the lack of patronage difference between these groups. Savvy consumers might like to think about or share their good deals with others (Feick and Price, 1987) to boost their self-image in others' eyes (Huddleston and Minahan, 2011).

\section{Managerial implication/limitation/future research}

Our findings have implications for retail managers. Results showed that consumers with high need for SIC patronize discount stores. This finding suggests marketing opportunities for discount stores such as Target, which might increase store patronage if they position clothing or home décor products using messages such as "Store X reflects my style" to resonate with consumers' need for self-image congruity. Discount stores might capitalize on social media message venues, such as versions of the YouTube show "The Haul", where men and women share favorite products and shopping venues. Concern about appearance is antecedent to the need for self-image congruence and leads to name-brand purchasing and patronage of both high- and low-end retail stores. Thus, marketing messages that focus on concern for appearance may be successful because they tap into the need for self-image congruence. We suggest that marketing messages that emphasize how the retailer's merchandise can help the customer "look her best" should resonate with consumers.

Although our study yielded interesting findings regarding consumers' need for self-image congruence in relation to retail store online and offline patronage behavior, further investigation is warranted. First, it would be fruitful to consider various types of discount stores, labeling and testing the effect of the need for self-image congruence on each type; future research could tease out variations in self-image congruence with a variety of discount stores to determine whether a specific store image influences the relationship between need for selfimage congruence and store patronage. Second, future research can test the effect of price-sharing information that might influence discount store patronage. Third, more factors need to be considered as possibly relating to discount store patronage behavior for high self-image consumers; our study only tested two possible mediators and did not find any relationships. Future research on the price maven effect, cultural factors (e.g. in certain cultures, people may share highprice purchases to show social status), lifestyle, personality characteristics and the relationship of these factors to discount store patronage, may offer deeper insights into more complex dimensions of self-concept theory than currently exists in the literature. If discount stores can identify the factors that lead to a match between self-image congruence and retail patronage, they may be able to pinpoint specific demographics or lifestyle characteristics that are strongly connected to those factors. For high-end department stores that operate in either offline or online channels, future research might test the relative importance of store characteristics such as price point, brand availability, store environment and channel choice.

\section{References}

Anderson, J.C. and Gerbing, D.W. (1988), "Structural equation modeling in practice: a review and recommended two-step approach", Psychologv Bulletin, Vol. 103 No. 3, pp. 411-423.

Baker, J., Levy, M. and Grewal, D. (1992), “An experimental approach to making retail store environmental decisions", Fournal of Retailing, Vol. 68, pp. 445-460.

Bollen, K.A. (1989), Structural Equations with Latent Variables, John Wiley \& Sons, Hoboken, NJ.

Brannick, M. (2003), "Scaling procedures: issues and applications", Personnel Psychologv, Vol. 56 No. 4, pp. 1088-1090.

Cash, T.F. and Labarge, A.S. (1996), "Development of the appearance schemas inventory: a new cognitive body-image assessment", Cognitive Therapv and Research, Vol. 20 No. 1, pp. 37-50.

Chebat, J.C., Sirgy, M.J. and Valerie, S.T. (2006), "Upscale image transfer from malls to stores: a self-image congruence explanation", Zournal of Business Research, Vol. 59 No. 12, pp. 1288-1296.

Dolich, I.J. (1969), "Congruence relationship between selfimages and product brands", Zournal of Marketing Research, Vol. 6 No. 1, pp. 80-84.

Feick, L.F. and Price, L. (1987), "The market maven: a diffuser of marketplace information", fournal of Marketing, Vol. 51 No. 1, pp. 83-97.

Felix, R. and Garza, M.R. (2012), "Rethinking worldly possessions: the relationship between materialism and body appearance for female consumers in an emerging economy", Psvchology E Marketing, Vol. 29 No. 12, pp. 980-994.

Fornell, C. and Larcker, D. (1981), "Structural equation models with unobservable variables and measurement error: Algebra and Statistics", fournal of Marketing Research, Vol. 18, No. 3, p. 382.

Gil, L.A., Kwon, K.N., Good, L.K. and Johnson, L.W. (2012), "Impact of self on attitudes toward luxury brands among teens", Fournal of Business Research, Vol. 65 No. 10, pp. 1425-1433.

Graeff, T.R. (1996), "Image congruence effects on product evaluations: The role of self-monitoring and public/private 
consumption", Psychology and Marketing, Vol. 13 No. 5, pp. 481-499.

Graeff, T.R. (1997), "Consumption situations and the effects of Brand image on consumers' Brand evaluations", Psychology and Marketing, Vol. 14 No. 1, pp. 49-70.

He, H. and Mukherjee, A. (2007), "I am, ergo, I shop: does store image congruity explain shopping behavior of Chinese consumers?", foumal of Marketing Management, Vol. 23 Nos 5/6, pp. 443-460.

Heath, A.P. and Scott, D. (1998), "The self-concept and image congruence hypothesis: an empirical evaluation in the motor vehicle market", European fournal of Marketing, Vol. 32 No. 11, pp. 1110-1123.

Hofstede, G. (1984), Culture's Consequences: International Differences in Work-Related Values, McGraw-Hill, Berkshire, p. 35 .

Hooper, D., Coughlan, J. and Mullen, M.R. (2008), "Structural equation modelling: guidelines for determining model fit", The Electronic fournal of Business Research Methods, Vol. 6, pp. 53-60.

Huddleston, P.T. and Minahan, S.M. (2011), Consumer Behavior: Women and Shopping, Business Expert Press, New York, NY.

Ibrahim, H. and Najjar, F. (2007), "A multi-dimensional approach to analyzing the effect of self-congruity on shopper's retail store behavior", Innovative Marketing, Vol. 3, pp. 54-68.

Jamal, A. and Goode, M.H. (2001), "Consumers and brands: a study of the impact of self-image congruence on Brand preference and satisfaction", Marketing Intelligence $\mathcal{E}$ Planning, Vol. 19 No. 7, pp. 482-492.

Jöreskog, K. and Sörbom, D. (1993), LISREL 8: Structural Equation Modeling with the SIMPLIS Command Language, Scientific Software International, Chicago, IL.

Jung, J. and Lee, S. (2006), "Cross-cultural comparisons of appearance self-schema, body image, self-esteem, and dieting behavior between Korean and US women", Familv and Consumer Sciences Research fournal, Vol. 34 No. 4, pp. 350-365.

Kline, R.B. (2005), Principles and Practice of Structural Equation Modeling, The Guilford Press, New York, NY.

Kressmann, F., Sirgy, M.J., Herrmann, A., Huber, F., Huber, S. and Lee, D. (2006), "Direct and indirect effects of selfimage congruence on Brand loyalty", Fournal of Business Research, Vol. 59 No. 9, pp. 955-964.

Lastovicka, J., Bettencourt, L., Shaw Hughner, R. and Kuntze, R. (1999), "Lifestyle of the tight and frugal: theory and measurement", Fournal of Consumer Research, Vol. 26 No. 1, pp. 85-98.

Lichtenstein, D.R., Ridgway, N.M. and Netemeyer, R.G. (1993), "Price perceptions and consumer shopping behavior: a field study", fournal of Marketing Research, Vol. 30 No. 2, pp. 232-245.

MacCallum, R.C., Browne, M.W. and Sugawara, H.M. (1996), "Power analysis and determination of sample size for covariance structure modeling", Psvchological Methods, Vol. 1 No. 2, pp. 130-149.

Markus, H. (1977), "Self-schemata and processing information about the self", fournal of Personality and Social Psvchologv, Vol. 35 No. 2, pp. 63-78.
Mittal, B. (2015), "Self-concept clarity: exploring its role in consumer behavior”, fournal of Economic Psychology, Vol. 46, pp. 98-110.

Nguyen, T., Ngamsiriudom, W., Pelton, L. and Dubinsky, A. (2015), "Interrelationships among facets of self, motivation, and conspicuous and sustainable consumption behaviour", International fournal of Business Science $\mathcal{E}$ Applied Management, Vol. 10 No. 2, pp. 16-31.

O'Cass, A. and Grace, D. (2008), "Understanding the role of retail store service in light of self-image: store image congruence", Psvchology \& Marketing, Vol. 25 No. 6, pp. 521-537.

Podoshen, J.S. and Andrzejewski, S.A. (2012), "An examination of the relationships between materialism, conspicuous consumption, impulse buying and Brand loyalty", Zournal of Marketing Theorv and Practice, Vol. 20 No. 3, pp. 319-333.

Podsakoff, P.M., Mackenzie, S.B., Lee, J. and Podsakoff, N. (2003), "Common method biases in behavioral research: a critical review of the literature and recommended remedies", Fournal of Applied psychologv, Vol. 88 No. 5, pp. 879-903.

Richins, M. (1987), "Media, materialism, and human happiness", in Wallendorf, M. and Anderson, P. (Ed.), NA Advances in Consumer Research (14), Association for Consumer Research, Provo, UT, pp. 352-356.

Rosenberg, M. (1979), Conceiving the Self, Basic Books, New York, NY.

Schwartz, S.H. (1992), "Universals in the content and structure of values: theoretical advances and empirical tests in 20 countries", in Zanna, M. (Ed.), Advances in Experimental Social Psvchologv, Vol. 25, Academic, Orlando, FL, pp. 1-65.

Sirgy, M.J. (1982), "Self-concept in consumer behavior: a critical review", The fournal of Consumer Research, Vol. 9 No. 12, pp. 287-300.

Sirgy, M.J. (1986), Self-congruity: Toward A Theory of Personality and Cybernetics, Praeger Publishers, New York, NY, p. 35.

Sirgy, M.J., Grewal, D. and Mangleburg, T. (2000), "Retail environment, self-congruity, and retail patronage: an integrative model and a research agenda", fournal of Business Research, Vol. 49 No. 2, pp. 127-138.

Sirgy, M.J., Grewal, D., Mangleburg, T.F., Park, J., Chon, K., Claiborne, C.B., Johar, J.S. and Berkman, H. (1997), "Assessing the predictive validity of two methods of measuring self-image congruence", fournal of the Academv of Marketing Science, Vol. 25 No. 3, pp. 229-241.

Sternquist, B., Byun, S.E. and Jin, B. (2004), "The dimensionality of price perceptions: a cross cultural comparison of Asian consumers", The International Review of Retail. Distribution and Consumer Research, Vol. 14 No. 1, pp. 83-100.

Wells, W.D. (1993), "Discovery-oriented consumer research", Zournal of Consumer Research, Vol. 19 No. 4, pp. 489-504.

Wiedmann, K., Hennigs, N. and Siebels, A. (2009), "Valuebased segmentation of luxury consumption behavior", Psychology and Marketing, Vol. 26 No. 7, pp. 625-651. 


\section{Appendix 1}

Table Al Characteristics of respondents (study 1)

\begin{tabular}{|c|c|c|}
\hline Patronage & Frequency & $(\%)$ \\
\hline \multicolumn{3}{|l|}{ Gender $(n=3,345)$} \\
\hline Male & 1588 & 47.5 \\
\hline Female & 1757 & 52.5 \\
\hline \multicolumn{3}{|l|}{ Age } \\
\hline $18-24$ & 163 & 4.9 \\
\hline $25-34$ & 654 & 19.6 \\
\hline $35-44$ & 739 & 22.1 \\
\hline $45-54$ & 707 & 21.1 \\
\hline $55-64$ & 485 & 14.5 \\
\hline 65 and over & 597 & 17.8 \\
\hline \multicolumn{3}{|l|}{ Marital Status } \\
\hline Married & 2266 & 67.7 \\
\hline Widowed & 203 & 6.1 \\
\hline Separated & 291 & 8.7 \\
\hline Divorced & 48 & 1.4 \\
\hline Single & 487 & 14.6 \\
\hline Other & 50 & 1.5 \\
\hline \multicolumn{3}{|l|}{ Income } \\
\hline Under $\$ 20,000$ & 526 & 15.7 \\
\hline$\$ 20,000-\$ 29,999$ & 359 & 10.7 \\
\hline$\$ 30,000-\$ 39,999$ & 335 & 10.0 \\
\hline$\$ 40,000-\$ 49,999$ & 333 & 10.0 \\
\hline$\$ 50,000-\$ 59,999$ & 325 & 9.7 \\
\hline$\$ 60,000-\$ 69,999$ & 279 & 8.3 \\
\hline$\$ 70,000-\$ 99,999$ & 522 & 15.6 \\
\hline$\$ 100,000$ or more & 477 & 14.3 \\
\hline No answers & 189 & 5.7 \\
\hline
\end{tabular}




\section{Appendix 2}

Table All Construct properties (study 1)

Items

Std. Factor Loading Composite Reliability Avg.Variance Extracted

Appearance

I work at trying to maintain a youthful appearance

I enjoy getting dressed up

0.56

0.60

0.81

An attractive appearance is crucial for career success

0.42

Self-image Congruence

The brands I buy are a reflection of who I am

The clothes I wear reflect who I am as a person

0.58

0.56

0.45

Brand Preference

When I have a favorite brand I buy it - no matter what else is on sale

I try to stick to well-known brand names

0.39

0.57

0.61

High-end (department stores) retail store patronage

Purchased clothes at a department store during the past 12 months

Purchased items for your home at a department store during the past 12 months

Low-end (discount stores) retail store patronage

Purchased clothes at a discount retailer during the past 12 months 


\section{Appendix 3}

Table Alll Construct properties (study 2)

Appearance

If I could look just as I wish, my life would be much happier

By controlling my appearance, I can control many of the social and emotional events in my life

my life

\section{Self-image Congruence}

When I consider the setting in which I will go to ___ the retail store where I would expect to purchase my job fair attire, I expect to see people who are similar to me in this store , the retail store where I would expect to purchase my job fair attire, are very much like me , the retail store where I would expect to purchase my job fair attire, is a mirror image of me

\section{Materialism}

I would like to be rich enough to buy anything I want

I'd be happier if I could afford to buy more things

It sometimes bothers me quite a bit that I can't afford to buy all the things that I would like

Frugality

I believe in being careful in how I spend my money

I discipline myself to get the most from my money

High-end (department stores) retail store patronage

The likelihood that I would shop for for the event in a department store is high.

I would be willing to buy ___ for the event in a department store I would recommend a department store where I would go to shop with my friends

Low-end (discount stores) retail store patronage

The likelihood that I would shop for for the event in a discount

store (TJMaxx, Ross, Marshall's) is high for the event in a discount store

I would recommend a discount store (TJMaxx, Ross, Marshall's) where I 


\section{Appendix 4}

Table AIV Results of hypothesis testing (study 1 and study 2)

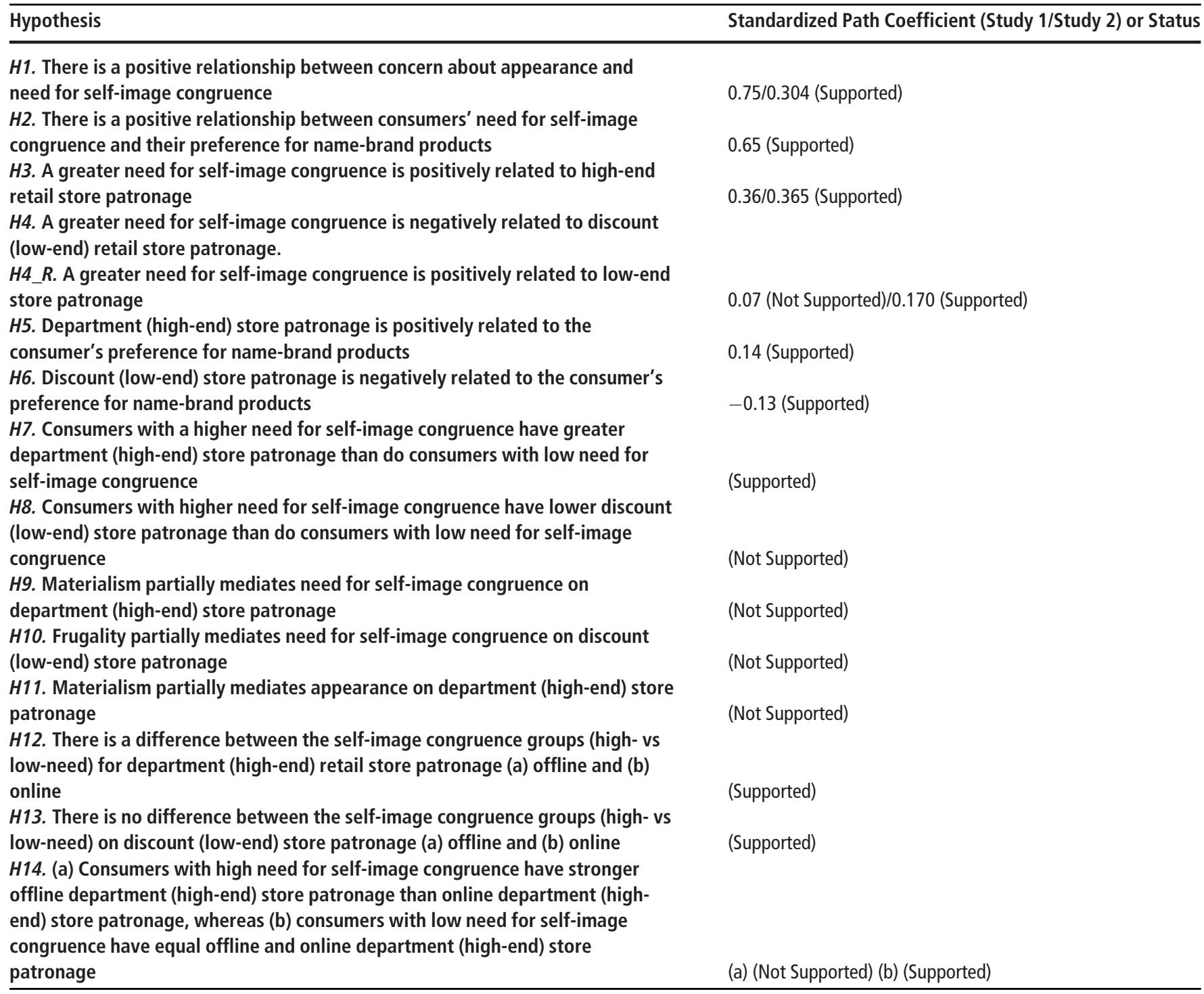

